\title{
Research Information Dissemination through the Conversion of Thesis and Research Reports into Publishable Articles by Teaching Staff
}

\author{
${ }^{1}$ Kutsanedzie $\mathrm{F}^{*}$., ${ }^{2}$ Ameko, E., ${ }^{2}$ Achio, S. \\ ${ }^{1}$ Accra Polytechnic Research and Innovation Centre \\ ${ }^{2}$ Science Laboratory Technology Department \\ *fkutsanedzie@apoly.edu.gh
}

\begin{abstract}
Theses and research reports of academic staff in various tertiary institutions are normally deposited on shelves in university libraries year in year out. However, the essence of these rigorous academic works is tailored toward solving identified problems. A three day Workshop was held for lecturers to learn and convert their theses and research reports into publishable articles for onward submission to peer reviewed journals for subsequent review and publication. Sixty (60) lecturers registered for the workshop by submitting softcopies of their respective theses and research reports. They were conducted through the Workshop by two facilitators who presented three topics on the subject: things to consider when converting theses and research reports to publishable articles; selecting journals for article publications; and tailoring theses and research reports to the format of the selected journals. The latter topic was done with working examples to enable the participants acquire the requisite skills. The participants were made to select a peer review journal per each of their formatted articles, and allowed to follow up the steps in converting their respective copies presented. The theses and research reports that were converted to papers were submitted to editors of the respective journals selected. At the close of the Workshop about ninety (90) articles were submitted to various journals for review and subsequent publication.
\end{abstract}

Keywords: Workshop, research publications, information dissemination, articles, peer review

\section{Introduction}

Research is one of the core functions of tertiary institutions in Ghana, and as such a duty for all lecturers in tertiary institutions in Ghana and beyond. Lecturers apart from carrying their individual research works are mandated to supervise the research projects of their respective students in the final year. Once the researches are carried out, the results churned out are expected to be disseminated to the targeted clientele to be utilized to solve the imminent developmental challenges in their immediate environ, in the country, sub region and beyond. So many research projects are produced annually by students under the supervision of lecturers. However, these are kept on shelves in libraries and cannot be accessed by the ultimate consumers of these pieces of information. According to Ogunrombi (1997), despite their value as original research, master and doctoral theses have traditionally been considered grey literature, due to their physical inaccessibility. However, some institutions such as Kwame Nkrumah University of Science and Technology (KNUST) store them in their institutional Dspace, thus making it accessible to all and sundry. Statistics indicate that theses that are made available in this way are more widely used and cited in ongoing research. Ogunniyi et al. (2011) indicated that there are many kinds of serials such as newspaper, magazines, newsletters, accessions, journals, indexes, abstract, reports proceedings and transactions of societies etc. Out of them all, journals are the most important to researchers because much of articles therein are products of research which may never appear in other publications. According to Ogunrombi (1997) serial publications form the backbone of any academic library because of their informational value. Olanlokun and Salisu (1988) revealed that journals are accorded prominence in the library because they provide the latest information in a discipline and if people want to be current in their field they have to read relevant journals.

Chamberlin (1999) revealed that if even one chooses to write one's thesis in the manuscript style, resulting chapters might still require significant revision if they need to be shortened and formatted later for a particular journal, and written with a broader audience in mind than one's dissertation committee. Lecturers in every tertiary institution are expected to have at least a master's degree coupled with not less than three 
years pool of experience. By virtue of the required qualification for lecturers employed to lecture in the tertiary institutions, it is expected that all of them should have their respective theses and research reports in their fields. However, most of these theses have not been converted into publishable articles for publication in peer-reviewed journals. This may be due to the fact that more emphasis is placed on teaching and less on publishing, or rather they lack the requisite skills needed in converting their theses into publishable standards.

Problem Statement: Though all lecturers of Accra Polytechnic have at least master's degree, most of their theses and research reports have not been published in peer reviewed journals which maybe due to the lack of skills in the art of converting their theses into publishable standards, and overemphasis placed on teaching at the expense of research activities.

Objectives of the Study: The study seeks to organize a three day workshop aimed at helping lecturers convert their theses and research reports to publishable standards. At the end of the Workshop is expected that lecturers submit articles prepared from their theses for publication in selected peer - reviewed journals; and also acquire the requisite skills to help them for their subsequent publication endeavours.

Justification of the Study: Large amount of money goes into research activities and the essence of these researches cannot be realized if its findings are not disseminated to the ultimate users of the findings. Theses of most lecturers that contained useful information are often not published and therefore wasted. Lecturers in various tertiary institutions as academics are not only mandated to teach but also to contribute to knowledge in their respective fields of qualification and lecture. The publication of researcher articles in peer-reviewed journals is a way of disseminating knowledge beyond the lecture halls. Publishing in journals does not only make lecturers contribute to knowledge but also keep them abreast of current trends in their respective fields, because of the literature reviewed while writing their research articles for publication. The conversion of thesis or research reports to publishable articles is therefore very relevant not only towards broadening of their knowledge but also tied to their promotion.

\section{Methodology}

Venue and Facility: In order to organize the 3-days Workshop on converting of thesis and research reports into publishable standards, a refurbished auditorium at Accra Polytechnic was used as the venue with full wireless internet connectivity provided by Vodafone - an internet service provider. A projector was installed and used for the presentation of the workshop materials.

Design and Administration of Workshop Forms: A registration form was designed and administered to lecturers to be filled and submitted by a stipulated deadline to the Research and Innovation Centre prior to the Workshop. The forms designed also indicated requirements for the Workshop as follows: all participants were to attend the Workshop with their personal laptops; participants were to submit softcopies of their theses and research reports; and also indicate their willingness and ability to prepare and submit article (s) to selected journals for peer review and subsequent publication at the close of the Workshop.

Workshop Materials: Workshop materials were sent to the registered participants via their emails provided on their registration forms. The materials included power point presentation to be made at the Workshop on the following topics: review of aspects involved in research article publication; selection of journals for publication; overview of formats of selected journals; tailoring of research projects to the format of a selected journal - working examples of a project report / thesis to a research article. In addition, samples of article acceptance letters from publishers as well as templates of various selected journals were sent to them.

Method adopted: The completed registration forms administered, and the softcopies of the participants' theses and research reports that were returned to the Research and Innovation Centre. The information on the forms were extracted, collated and used for the planning of the Workshop. An attendance register was kept for the Workshop. In order to keep the lecturers at the venue for the Workshop, snack and lunch was given during all the three days. The workshop commenced at 9:00 am and closed at 4:30 pm daily. Four presentations were made by two facilitators with participants allowed to ask questions at the end of each of 
the presentations. The last presentation which was practice-based dwelt on tailoring of research projects to the format of selected journals: working examples of a project report / thesis converted into a research article. This was made interactively as much as possible. The participants were told to follow the facilitator instructively in a stepwise fashion using soft copies of their respective works: select a journal; download the author's guide; download the template; structure your title; write an introduction to the work, state the problem statement and objectives of the paper; structure the methodology; present the results and do discussion; structure the conclusion and recommendation; and structure the references according to the format required by the selected journal. The facilitators moved around and addressed questions that begged of variability in the formats of the selected journals. For the second and third days of the Workshop, participants worked on formatting their works according to their selected journals' specifications.

\section{Results and Discussion}

Table 1: Statistics of Attendees at the Workshop on converting of Thesis and Research Reports into Publishable Standards

\begin{tabular}{lll}
\hline Department & Male & Female \\
\hline Civil Engineering & 1 & 1 \\
Hotel Catering and Institutional Management & 1 & 3 \\
Fashion Design & 1 & 6 \\
Science Laboratory Technology & 5 & 1 \\
Accountancy & 9 & 0 \\
Mechanical Engineering & 1 & 0 \\
Statistics and Mathematics & 4 & 2 \\
Marketing & 1 & 0 \\
Purchasing and Supply & 5 & 1 \\
Secretary and Management & 2 & 3 \\
Liberal Studies & 1 & 1 \\
Computer Science & 2 & 1 \\
Building Technology & 0 & 1 \\
Furniture & 1 & 0 \\
Total & 34 & 20 \\
\hline
\end{tabular}

At the end of the three day Workshop organized, the articles prepared and submitted for peer reviewing for publication by the participants in their respective selected journals are captured in table1. Most of the participants were able to convert their theses into publishable standards. However, those lecturers who completed their theses about five years and beyond prior to the Workshop were required per the instruction guide of some journals to update to their literature because they were obsolete. This made some of the participants unable to send their articles by the close of the Workshop. It is a common belief that if work is not published in a timely manner, it is unlikely to be published at all. Also, in order for a journal to accept an article from authors, it is required that authors follow strictly the format and writing style of the prospective journal. This is confirmed by that one needed to tailor the writing and formatting style of the dissertation towards specific journal requirements in order to get them published (Rudestam and Newton, 1992; Luey, 2004). There was also a general problem on summarizing the theses and projects reports according to the number of pages required by the journals. It afforded the participants the opportunity to learn how to summarize their findings with clarity and brevity. It presented a huge task as participants struggled to reduced sometimes between 150 - 120 page theses and research reports to 12 - 14 pages maximally in order to avoid incurring extra charges in U.S $\$ 50$ per page or sometimes per word. For this, Chamberlin (1999) noted that the process of converting dissertations to publishable articles teaches graduate students not only to summarize research findings in a succinct manner, but also how to communicate to a broader audience than faculty and committee members.

Access to research output by scientists and researchers is of vital importance in any given geographical region, including the African continent which is challenged with so many developmental needs; so urgent are Africa's needs that the effective dissemination of this knowledge is to a certain extent a matter of life and death (Onyancha and Jacobs, 2009). Though many masters theses and doctorate dissertations are produced 
yearly, students of these are not compelled to publish them before they graduate with their respective degrees in most Africa universities, thus the research outputs which is needed to help confront some of the developmental challenges of the continent persist. Though it is the expectation that if all these research outputs are disseminated and made available through publication, many of the continents problems are likely to be confronted, Onyancha and Jacobs (2009) indicated the use of foreign-based research outputs to inform decision making processes in the African continent is a common practice. African research knowledge is either locked inside international publications that are too expensive for African university libraries and scholars, or published in local journals that are relegated to the second rank by a global system that does not value them.

Most tertiary institutions in Africa do not disseminate findings from research projects and theses of their students via publication and this is confirmed in a study by Gray (2006) that the university system across sub-Saharan Africa does not generate publications or disseminate research findings effectively enough to reach the audiences that need to make use of development-focused research from within the continent. It therefore makes organizing workshops such as done very cogent in helping get the research outputs which would not have found their way to the public for utilization published. This is also confirmed by Cunha (2000) that when a thesis is defended, it moves to the condition of scientific literature, serving as a source of knowledge to other scholars. Its importance is that new ideas and findings are not limited to their holders only; they are widely disseminated to play the role assigned to them in the construction and development of science. Most of the research reports and theses' titles that have been converted to publishable standards and submitted to different journals for publication identified problems that largely face the researchers' immediate environs that needed to be tackled. Rey (1978) highlights that production of scientific information and its communication form part of a complex system, which operation is essential to the development of scientific knowledge. It thus suggests that without the dissemination of the information contained in these theses and research reports development of scientific knowledge geared towards development would elude us as a people and a nation.

\section{Conclusion and Recommendations}

Though there was initial internet connectivity problem, it became stabilized at the later part of the Workshop. As of the last day of the Workshop, close to forty (40) written articles were submitted by participants to various journals with most of them receiving acknowledgement of receipt of their articles by the editors of the respective journals. It is the view of the authors that when such workshops are organized for academics in various tertiary institutions to build their capacity as well as help them to convert their theses and research projects into publishable forms for publication in peer reviewed journals. When lecturers are equipped with these skills, it will have a reciprocal effect on students in terms of them getting their project works published for dissemination of the knowledge. When theses are published, the knowledge generated by students and lecturers would not be kept perpetually on library shelves. There was a general call by the participants for frequent organizing of such workshops because of the immense benefit as regard the knowledge acquired and the practical skills acquired by participants over the three days period.

\section{References}

Chamberlin, J. (1999). Unpublished? Try your dissertation. APA Monitor Online, 30(11). Retrieved 3 February 2008 from website: http://www.apa.org /mon itor/ /ed1 html on.

Cunha, J. V. A. (2000). Doutores em Ciências Contábeis da FEA/USP: análise sob a óptica dateoria do capital humano. Tese de Doutorado - Faculdade de Economia e Contabilidade da Universidade de São Paulo. São Paulo: FEA/USP, 2000.

Gray, E. (2006). At the South-eastern frontier: the impact of higher education policy on African research publication. Unpublished conference paper, Codesria-ASC conference series 2006: Bridging the North South Divide in Scholarly communication: Threats and opportunities in the Digital Era, August 21-22, Leiden.

Luey, B. (2004). Revising your dissertation: Advice from leading editors. University of California Press., California. 
Ogunniyi, O. S., Akerele, A. J. \& Afolabi, A. F. (2011). Use of Serial Publications by the Academic Staff of School of Arts and Social Sciences in Adeyemi College of Education Ondo State, Nigeria. Retrieved on $8^{\text {th }}$ January 2014 from http://www.web pages .uidaho .edu/ mbolin /ogunniyi-akerele-ofolabi.htm.

Ogunrombi, S. A. (1997). Serials Selection and Deselection: a Survey of Nigerian University Libraries. African Journal of Library, Archives and Information Science, 7(1), 33-42.

Olanlokun, S. O. \& Salisu, T. M. (1988). Understanding the Library: A Handbook of Library Use. Lagos: Concept.

Onyancha, O. B. \& Jacobs, D. (2009). Capacitating national research: a review of South African natural sciences research projects, theses and dissertations, 1986-2006. SA Jnl Libs \& Info Sci., 75(2), 117 130.

Rey, L. (1978). Como redigir trabalhos científicos. São Paulo: Ed. Edgard Blücher Ltda.

Rudestam, K. E. \& Newton, R. R. (1992). Surviving your dissertation: A comprehensive guide to content and process. Newbury Park, CA: Sage Publications.

\section{APPENDIX}

Table 2: Papers that Received Acceptance for Publication in various Journals

\begin{tabular}{ll}
\hline No. & Title of Research Papers \\
\hline 1 & $\begin{array}{l}\text { Evaluating of procurement Processes and its Operational Performance } \\
\text { in the Public Sector of Ghana: A case study of Komfo Anokye Teaching }\end{array}$ \\
2 & $\begin{array}{l}\text { Hospital and Kumasi Polytechnic } \\
\text { Assessing the Role of Outsourcing in a Financial Institution: the Case } \\
\text { Study of Prudential Bank Limited (Ghana) }\end{array}$
\end{tabular}

3 Improving Productivity at the currency Processing Centre (Bank of Ghana) through Six Sigma

$4 \quad$ The relationship between loan default and Repayment Schedule in Microfinance Institution in Ghana: A Case Study of Sinapi Aba Trust

5 Management of Government Funded Construction Projects in Ghana: Stakeholders' Perspective of Causes of Delays in Construction of Public Buildings

6 Entrepreneurship Promotion for Sustainable Development in Ghana

$7 \quad$ An Exploratory Study of Entrepreneurial Leadership Development of Accra Polytechnic Student

8 Stock Market Capitalization and Economic Growth

9 A Risk-Based Assessment of ECOBANK Ghana Limited

10 An Evaluating of the Risk Profile of the Banking Industry in Ghana and its Implication on the National Economy

11 Determining Factor Affecting Corruption: A cross Country Analysis

12 Alternative way of Managing Plastic Waste on Compuses

13 Novel Photovoltaic Module's Model using Matlab and Simpowersystem

14 Business process Reengineering (BPR) in the Financial Service Sector: A Case Study Ghana Commercial Bank (GCB) Limited

15 Challenges of Single Ordained Women Ministers in the Presbyterian Church of Ghana

Name of Journals

International Journal for

science Technology and

Education

International Journal for science Technology and Education

International Journal for science Technology and Education

International Journal for science Technology and Education

International Journal for science Technology and Education

Journal of Economic and Sustainable Development

Journal of Education and Practice

Research Journal of Finance and Accounting

Research Journal of Finance and Accounting

International Journal of Economic , Finance and Management Science International Journal of Economic, Business and Finance

International Journal of Development and Sustainability International Journal of Computer Applications (IJCA)

European Journal of Business and Management Canadian Social Science 
16 Evaluating the Accra Polytechnic Examination System for Total Quality Management Principles

17 Overview Facility Management Financing in the Construction Industry In Accra , Ghana

18 The Impact of Innovation of the Construction Industry in Ghana

19 The management of Health and Safety of Construction Site in Accra

Evaluating the success Factors of Partnering in the building Construction Industry in Accra Metropolis

21 Divisional Performance Evaluation Tools Employed by Indigenous Ghanaian Banks

22 The love of Beads among the Ghanaian

Reflections on the Impact of Competency Based-Training Pedagogy on Fashion Design Education at Accra Polytechnic Optimizing Acceptability of Fresh Moringa Oleifera Beverage

Characterization of Fresh Moringa Oleifera Beverage

Risks Associated with Geophagia

Discriminant Analysis of Discrimination Against people with Disability

Determinants of Polcyclic Aromatic Hydrocarbons in Smoked Meat

Scottish Entrepreneurship Education

Phenotypic Determination and Antimicrobial Resistance Profile of Extended Spectrum Beta-lactamases in Escherichia coli and Kelebsiella pneumonia in Accra, Ghana

31 The Reliability of using Vitek 2 compact System to Detect ExtendedSpectrum Beta lactamase-producing Isolate in Escherichia coli and Klebsiella pneumonia in Accra, Ghana

32 Phenotypic characterization of Ampc beta-lactamase among Cefoxitin Resistant Escherichia coli and Klebsiella pneumonia Isolate in Accra, Ghana

33 Bank and Customer Service Delivery: Attracting and Retaining Customers in Ghanaian Banking Sector

34 Celebrity Endorsement and consumer Buying Behavior, Enhancing the Promotion function of Marketing in the Central Business Area of Acccra

35 Customer Retention in the Ghanaian Mobile Telecommunication Industry

36 Supply chain Cost Identification as a Means of Cost Reduction StrategyA case Study of Ghana Supply company Limited

37 Assessing the Alignment between Students of the Department of Secretaryship/Bilingual Secretayship and Management Studies of Accra Polytechnic

38 Medical Waste Disposal Practices in Some Hospitals and Clinical Laboratories in the Accra Metropolis

39 The Potency of some Brands of Anti-Diabetic Medicine- Metfromin Hydcloride BP 500mg Tablet on the Ghanaian Market

40 Personal Values: A Preceptual lens for investigation spousal perception of Marital Conflict among Ghanaian dual Career Couples
International Institute for Science, Technology and Education

Research Journal of Finance and Accounting

Journal of Civil and Environment Research

Journal of Civil and Environment Research

Industrial Engineering Letters

Research Journal of Finance and Accounting

The International Institute for Science

The International Institute for Science Journal of Food Science and Quality Management Journal of Food Science and Quality Management

Canadian Journal of Pure and Applied Science

Research on humanities and Social Science

International Journal of Nutrition and Food Science Journal of Education and Practice

Journal of Natural Science Research

Advance in life Science and Technology

Journal of Biology, Agriculture and healthcare

European Journal of Business and Management

European Journal of Business and Management

European Journal of Business and Social Science European Journal of Business and Management European Journal of Business and Management

Civil and Environmental Research

Chemistry and Material Research

America Journal of Applied Psychology 
41 Structured Query language Injection (SQLI) Attack: Detection and Prevention Techniques is Web Application Technology

42 Towards a Perspective of Web Application vulnerabilities and Security Threats

43 Towards a Perspective of Computing Related Programmes Offered by Public Tertiary Institution in Ghana

44 Quality Assessment of Aqueous Herbal/ Medicinal Products Sold on the Ghanaian Market

45 Connecting the world of Learning and work: The Role of the World of Work Programmes

46 Competency Based Training: Quality Delivery for Technical and vocational Education and Training

47 Effect of human Resource Management Practices on the Performance of Small and Medium Hotels of Osu Klottey Sub Metropolitan Assemble of Greater Accra

48 Using demonstration Methods to Enhance the Performance of First year High National Diploma (HND) Secretaryship Studies of Accra Polytechnic in Typewriting

49 Effect of Recruitment and Selection practice on the Performanc of Small and Medium Hotels of Osu Klottey Sub-Metropolitan Assembly of Greater Accra

50 A comparative study of impact of Ghanaian Public Procurement Processes before and after the Enactment in 2003 - A case study of Accra Polytechnic

51 Automated Business Name Reservation and Registration System - A case Study of Registrar General's Department, Ghana

52 Semi-Automatic Car Anti-Theft Design using a ATMega168 Microcontroller

53 Design of a Fast and Automomous Complex Line Tracker and Fully Controlled Robot by limit Switches

54 Performance Analysis of Femtocell in an Indoor Cellular Network

The Evaluation of Banks in Ghana using Financing Ratios: the Case study of Barclays Bank, GCB ADB

56 Water source and Water Demands Assessments for Bonwire

57 A Critical Analysis on Advertising Banks Products and Services in Ghana

58 Assessing the Impact of Effective Institutional Capacity on Advocacy for Microfinance Firm- Case study of Northern Ghana

59 Assessing Rural Banks Effectiveness in Ghana

60 Polytechnics as Institutions for Intraregional Collaboration for Skills Development in Africa

61 Measuring Poverty: The Methodological Debate

62 Evaluating Venture Capital Financing Using Principal Components Analysis
International Journal of computer Application

International Journal of computer Application

International Journal of Computer Science and Telecommunications

Food Science and Quality Management

Educational Research International

Educational International

International Journal of Business Management

Journal of Education and practice

Developing Country Studies

European Journal of Business and Management

International Journal of Computer Application

International Journal of Computer Application

International Journal of Computer Application

International Computer

Networks and Wireless

Communications

IISTE

Civil and Enviroment Research of the IISTE International Journal of Marketing Studies

International Business

Research

International Business

Research

Journal of Education and Vocation Research

IISTE

IISTE 